\title{
The Nature of Gender: work, gender and environment
}

The final version of this manuscript appears in: Environment and Planning D: Society and Space 24:2

Andrea Nightingale, Ph.D.

School of Geosciences

Geography, Drummond Street

University of Edinburgh,

Edinburgh EH8 9XP, Scotland, UK

anightin@geo.ed.ac.uk 


\section{Copyright}

This online paper may be cited in line with the usual academic conventions. You may also download it for your own personal use. This paper must not be published elsewhere (e.g. mailing lists, bulletin boards etc.) without the author's explicit permission

Please note that :

- $\quad$ it is a draft;

- $\quad$ this paper should not be used for commercial purposes or gain;

- you should observe the conventions of academic citation in a version of the following or similar form:

Andrea Nightingale (2006) The Nature of Gender: work, gender and environment, online papers archived by the Institute of Geography, School of Geosciences, University of Edinburgh. 
Gender has long been recognised as important within environmental issues, but exactly how and in what contexts it is relevant has been hotly debated. As feminist theorising around women and gender has changed, so have conceptualisations about gender and environment, leading to a key debate within ecofeminism and related literatures about whether there is an essential or a contingent relationship between women and natural environments. Within geography, most political ecologists work with the assumption that the gender-environment nexus is a contingent relationship, and thus investigate how gender relations are salient in the symbolic and material construction of environmental issues. This paper seeks to build from this work and again raise the question of how gender is conceptualised in relation to environment. I begin by briefly reviewing some of the work that has been done on gender and environment and then draw from post-structural feminism to suggest that gender itself has been under-theorised in work on environment. Once gender is re-conceptualized as a process, the dynamic relationship between gender, environment and other aspects of social and cultural life can be brought into view. What emerges is the need for political ecologists to examine gender beyond the household and community and the need to re-conceptualise the gender-environment nexus. A case study of community forestry in Nepal is used to illustrate the importance of interrogating the processes by which gender relations become salient and are reproduced symbolically and materially.

Keywords: political ecology, nature, gender, Nepal, community forestry 


\section{The Nature of Gender: work, gender and environment}

\section{Introduction}

Gender has long been recognised as important within environmental issues, but exactly how and in what contexts it is relevant has been hotly debated. Some feminists have argued that there is a natural or essential connection between women and nature which gives women an innate understanding of ecosystems and environmental protection (Diamond and Orenstein 1990, Shiva 1988). This kind of essentialist thinking has been challenged by other feminists who instead focus on the material practices that bring women closer to nature and thus gives them learned, practical knowledge of ecosystems (Agarwal 1992, Warren 1987). Within geography, many political ecologists have embraced a historical materialist argument and focus on gender as one relation through which access to and distribution of natural resources is differentiated within societies (Carney 1994, Fortmann 1996, Freidberg 2001a, Gururani 2002, Mackenzie 1995, Rocheleau, et al. 1996b, Schroeder and Suryanata 1996). In this work, gender is closely linked to biological sex and understood as culturally defined male-female roles. Such studies have documented how women are denied access to new technologies, training and other benefits of development projects, and given limited access to and control over land and natural resources (Barker 2000, Carney 1996, Deere and Leal 1981, Moser 1993, Nathen 1995). What remains generally unaddressed, however, is how such inequality is maintained over time and space, particularly in societies where women shoulder the bulk of the agricultural work.

In this paper, I explore the production of social inequalities and environments by examining how and when gender and other forms of difference become enrolled in 
environmental issues. I draw on definitions of gender that imagine it as a process by which subjectivities are produced and shift over time and space (Butler 1990, 1997, Connell 1987, Mahoney and Yngvesson 1992, Mehta and Bondi 1999), rather than part of power-laden systems of social structures. The meaning and relevance of gender is thus produced in space and in part constitutes that space such that neither can pre-exist the other (Bondi and Davidson 2004, Massey 1994, McDowell 1999, Pratt and Hanson 1994). If gender is unable to pre-exist its context, then the focus of gender-environment studies needs to shift to how gender becomes relevant in environmental disputes and how gendered subjectivities are (re)produced in environments (see also Bondi and Davidson 2004).

This conceptualisation emphasises that gender is not constant and pre-determined materially or symbolically but rather becomes salient in environmental issues through work, discourses of gender and the performance of subjectivities. Inequalities between men and women are not only a consequence of environmental issues, gender is a cause of environmental change in the sense that gender is inextricably linked to how environments are produced. When gender is conceptualised as a process, the complex interplay between gender, environment and other relevant aspects of social and cultural processes can be analyzed. In the second part of the paper I draw on a case study of community forestry in Nepal to illustrate these dynamics in a placebased development project. Before turning to the case study, I review the literature on gender and environment and suggest that if these post-structural insights are used to re-conceptualise gender, then gender-environment nexus also needs to be re-theorised.

\section{Gender and Environment}

In this section I highlight three key strands discernable in existing work on gender and environment to demonstrate how gender has been treated conceptually and 
the complexity of thinking within this literature (for good reviews see Agarwal 1992, Moeckli and Braun 2001, Nesmith and Radcliffe 1993, Rocheleau, et al. 1996b). First, I briefly discuss the contributions as well as the limitations of essentialist thinking about gender and environment (see also Bondi and Davidson 2004). In this strand, there is an assumption of an 'inherent' or 'natural' connection between women and the land providing women with privileged knowledge of environmental change and privileged roles in redressing environmental destruction (Diamond and Orenstein 1990, Mies and Shiva 1993, Shiva 1988). Second, I outline work that emphasises the material practices that shape the relationships between gender and environment. This strand argues for a contingent, production-based relationship between gender and environmental knowledge and action (Agarwal 1992, Plumwood 1991, Warren and Cheney 1991). Third, I discuss more recent work done in geography that brings together these perspectives with insights from political ecology to highlighted gendered knowledges, rights and politics in the context of environmental issues (Freidberg 2001a, Rocheleau, et al. 1996b).

\section{Essentialist conceptualisations of gender-environment}

In the mid-1970s feminist scholars began to examine the dualistic associations that aligned women with nature and men with culture (Griffin 1978, Ortner 1974). These associations were linked to a host of binary structures such as men are rational and women emotional, women are nurturing whereas men are competitive (Haraway 1991, Merchant 1982, Ortner 1974). In response to this, some feminists embraced the idea that women are closer to nature and, in the context of the growing environmental movement, argued that women inherently have a better understanding of the importance of environmental protection (Diamond and Orenstein 1990, Mies and 
Shiva 1993, Shiva 1988). This ecofeminist thinking was premised on the idea that the domination of women was linked to environmental destruction and other problematic social inequalities such as racism. Susan Griffin's (1978) book Women and Nature: the roaring inside her, was an important piece of lyrical writing that helped inspire ecofeminism. In this book, Griffin uses poetry and evocative writing to equate the violence done to the land with violence done to women. Importantly, she puts forward the idea that women, like nature, could and were fighting back, using their 'nature' to do so.

This kind of work promoted an essentialist notion of women that was common within feminism at the time. 'Women' was a largely undifferentiated category and it was assumed that all women would have the same kind of sympathies and understandings of environmental change as a consequence of their close connection to nature. Vandana Shiva's (1988) book, Staying Alive: Women, Ecology and Development is perhaps one of the most famous examples to come out of this kind of thinking. ${ }^{1}$ This book discusses the grassroots Chipko movement in northern India and the symbolic resources they drew upon to save their forests from commercial loggers. In it she argues that Indian women have an inherent connection to nature, and the power that arises from that connection inspires them to risk their lives in front of logging machinery. Although women are oppressed and marginalised in modern Indian society, Shiva draws from ancient religious beliefs and stories to suggest that women are in fact more powerful than men, and certainly have a more profound understanding of environmental change. This work was incredibly important in promoting the idea that uneducated people (especially women) could have a better understanding of environmental protection than scientists and policy makers. It was

\footnotetext{
${ }^{1}$ While in some ways I am criticising her work here, I want to acknowledge that it was Vandana Shiva's work that first inspired my interests in gender, development and environment. She and Bina Agarwal have been extremely influential on my thinking about these issues.
} 
also important in advocating for a global women's movement, linked together by threats to women's home environments (see also Seager 1993). Shiva asserted that the inherent understanding women have of their environments would help to bridge cultural gaps and provide a focus around which they could join together globally. While heavily criticised both within India and by other feminists for inaccuracies in her work and problematic assumptions about different women's experiences, Shiva's work has inspired women all over the world to defend environmental resources and was central in making 'Chipko' a household name in many places.

Other key ecofeminists focused on the ideological assumptions of modern science that are based upon dominating 'mother nature' (Merchant 1982, Mies and Shiva 1993, Plumwood 1991, Warren 1987). They argued that there are close connections between patriarchy and modern transformations of environments. Thus the reversal of environmental destruction cannot fully occur without the emancipation of women. In this kind of conceptualisation, gender, based on biological sex, is the foundational relation that serves to support other problematic relations such as race, class, and heterosexism (Plumwood 1991, Warren 1987).

\section{Materialist conceptions of women-environment}

Conceptualising the relationship between women and nature as an essential one thus helped to define a global women's environmental movement and challenged the hegemony of (male) scientific knowledge as the privileged source of information about environmental change. However as other feminists argued, essentialist conceptualisations of women ignored very real differences that exist between women and worse, rely on the notion of an essential female nature (Cuomo 1998). Women of colour in the United States were some of the first feminists to challenge the white, 
middle class bias in feminism (hooks 1984, Moraga and Anzaldua 1988). Latino and African American women argued that in many contexts race was more salient in shaping their experiences of inequality and thus the intersections of race, class and gender need to be theorised (hooks 1990, Kobayashi and Peake 1994, Moraga and Anzaldua 1988).

In India, Bina Agarwal (1992) challenged Shiva's essentialist rendering of the women and environment nexus, drawing from her own work on women and fuelwood issues in the Himalayas. She argued that while indeed a relationship between women and their motivation to protect the environment could be identified, this relationship was based on their material realities and not some inherent, close connection to nature. Many Indian women are responsible for the food and fuel needs of their families, activities that require them to tend the land and gather products from forests (Agarwal 1994, Gururani 2002). These activities give them intimate knowledge of their ecosystems and a strong need to ensure resources are used sustainably; failure to do so results in increased work burdens for themselves (Agarwal 1994, 1997). She named this brand of theorising 'ecological feminisms' to distinguish it from the essentialist conceptions of women that were beginning to dominate the ecofeminism literature (Agarwal 1992).

Ecological feminisms argued for a clear focus on gender, defined as the differences between men's and women's experiences and knowledge in relation to environment. This focus illuminates the importance of material practices, in particular men's and women's work practices, and culturally-specific gender roles in shaping the gender-environment nexus. It also builds on ideas already put forward by Shiva and others that rural women's environmental knowledge is valid and important. By basing this claim on material practices, Agarwal helped to give an empirical basis 
to the idea that women have unique environmental knowledge and significantly, brought a political economic analysis into the debate around gender and environment. She argued that the material conditions of people's lives are complicit in producing particular kinds of environmental problems, and these problems place extra burdens on women responsible for the subsistence needs of their families. Thus attention to political economy as well as to cultural expectations and behaviour around gender are important in analysing environmental issues.

\section{Feminist political ecology}

Building from ecofeminism and ecological feminism, the book, Feminist Political Ecology, edited by Diane Rocheleau, Barbara Thomas-Slayter and Esther Wangari (1996b) laid out what they saw as the three key themes to emerge from feminist theorising on gender and environment and recent political ecology work:

1. Gendered knowledge, or the ways in which access to scientific and ecological knowledge is structured by gender

2. Gendered environmental rights and responsibilities, including differential access by men and women to various legal and de facto claims to land and resources.

3. Gendered politics and grassroots activism, including an examination of women within and as leaders of environmental movements.

The first theme, gendered knowledge, follows much of the feminist environmentalism literature and explores how men and women have differential knowledge of natural resources. For example, men often have privileged access to agro-forestry extension workers, new training opportunities and other knowledge associated with 'science', (Diamond and Orenstein 1990, Rocheleau, et al. 1996a, 
Wangari, et al. 1996) while women have experiential knowledge gained from their role as subsistence providers in households. Rocheleau et. al. (1996) use this information to demonstrate that women often have crucial knowledge of natural resources that allows for household survival and to argue that women should be included more centrally in development projects and extension work.

The second theme, gendered rights and responsibilities, explores the contexts within which women are denied equal access to land and resources. In many Third World contexts, agrarian reforms legally distributed land to male heads of households only, undermining women's de facto claims to use-rights and control over land (Bourque and Warren 1981, Chant and Radcliffe 1992, Deere 1990, Gisbert and al. 1994, Radcliffe 1992). Current development projects often intersect with these conflicts over land and resources to the detriment of women (Carney 1996, Rocheleau, et al. 1996a), although such negative effects are acknowledged to be spatially and temporally specific (Agarwal 1994, Carney 1996, Schroeder 1997). The importance of recognizing complex land rights systems within development processes is illuminated by this theme. Redefining land rights in terms of private property often creates significant social justice consequences, particularly for women (Agarwal 1994, Carney 1996, Gururani 2000, Rocheleau and Edmunds 1997).

The third theme, gendered politics and grassroots movements, examines social movements but includes a specific focus on the role of women within them, highlighting how they have been empowered through involvement in community struggles for control over natural resources. While certainly not without their contradictions, environmental social movements are seen to have tremendous potential for the emancipation of women and impoverished communities in addition 
to environmental protection (Escobar 1995, Peet and Watts 1996a for an alternative argument see, Reed 2000).

In summary, most of the work done within feminist political ecology demonstrates how gender, understood as culturally defined male-female sex roles, structures access to particular types of knowledge, space, resources and socialpolitical processes (cf. Carney 1996, Freidberg 2001a, Rocheleau, et al. 1996b). The focus on these structures provides an important foundation for arguing that men and women have differential opportunities and challenges in relation to environmental change and development. Feminist political ecology provides tools for political ecologists to examine gender and emphasises the importance of considering gender in the context of a variety of natural resource issues. The emphasis within feminist political ecology, however, has largely remained on women and indeed, in places in Rocheleau et al.'s book 'gender' seems synonymous with 'women'. There is a danger in such a conceptualisation of falling back into essentialist understandings of women and their 'natural' connection to the land. This kind of essentialism masks a variety of political economic, cultural and symbolic processes by which gender is produced by environmental issues as well as being implicated in the construction of the 'issue' itself. In short, what is still not sufficiently highlighted, is a clear understanding of how gender has come to be relevant in these contexts at all.

\section{Towards a re-conceptualisation of gender-environment}

Within the mainstream development literature, gender politics are assumed to be most salient at local scales. Feminist political ecology has shown how women's knowledge and differential access and rights are important at a variety of scales, yet the larger political ecology literature continues to treat gender as primarily relevant 
only within households and communities (cf. Bryant 1998, Peet and Watts 1996b). Richard Schroeder's (1997) work on gender and development in the Gambia has been an important corrective to this and has illustrated how gender is salient at the level of international policy. He demonstrates how gender relations are contested in the context of development projects through an examination of international projects designed to benefit women. These projects were undermined by subsequent projects that had an explicit environmental focus leading to the demise of gains made by the women-centric projects (see also Mackenzie 1995, Schroeder 1997, Schroeder and Neumann 1995, Schroeder and Suryanata 1996). Through gendered property rights, men were able to reassert their claims to land that women had improved under earlier women's projects (Schroeder 1997). This kind of analysis demonstrates how gender relations become significant in shaping environmental disputes and can lead to unexpected outcomes (Carney 1996, Freidberg 2001a, Freidberg 2001b, Gururani 2002, Rocheleau and Edmunds 1997). It further shows how gendered rights and access to land are reconfigured through development projects. In this case, and that of Judith Carney's work on the Gambia $(1994,1996)$ women's rights to particular plots of land and their labour input requirements were re-negotiated as development projects promoted new cultivation regimes and access to markets. As a consequence not only were men's and women's roles reconfigured, but environmental change was closely linked to these struggles over roles and resources.

In India, Gururani (2002) has argued for the need to re-conceptualise nature in relation to gender. She draws from post-structuralist thinking on nature (Braun and Castree 1998b, Haraway 1991, Latour 1993, Swyngedouw 1999) to suggest that 'forests' are formed from the social-politics of work, access and control as well as the biophysical aspects of them. She uses a case study of forestry in the Kumaon 
Himalaya to illustrate her argument. In her work, there is an implicit understanding that social relations constitute environments and are transformed through daily interactions of people, forests and work, providing an excellent foundation from which to examine the mutual constitution of social relations and environments. In her work, however, the focus is on re-conceptualising nature, and the meanings of gender are not made entirely explicit.

My analysis here builds on this work in examining not only the ways in which gender relations shift within community forestry in Nepal, but also how gender and other subjectivities, such as caste, are constituted and contested. What I am suggesting is that there is a need to examine not only how gender roles change, but also how gender as a socially constructed concept is re-inscribed by struggles over resources. How does the construction of subjectivities, such as gender and caste, become significant in shaping the outcome of environmental issues? Through what struggles and contestations are these subjectivities (re)defined? While Carney, Schroeder and Gururani examine how gender roles and social relations are reconfigured, they fall short of demonstrating how what it means to be a man or a woman is (re)inscribed by the struggles they describe.

My argument also links explicitly to ecological conditions to examine how these struggles in part produce environments materially and symbolically (see also Gururani 2002). Many political ecology studies treat the ecological environment as a background or context (Bryant 1998, Escobar 1995, Peet and Watts 1996a, Sundberg 1998) although some more recent work has attempted to engage more directly with ecological change (Sneddon 2000, Swyngedouw 1999, Zimmerer 2000). Within mainstream environmental debates, it is the environment that is the focus of attention. If the environment is at risk, it is difficult to make a clear argument about why we 
need to care if men and women have a different experience and knowledge of that risk, especially when the consequences of such differences vary from context to context. But, if gender is a process that becomes significant in contingent and specific ways with variable and unpredictable ecological outcomes, then gender relations need to be analyzed as both a fundamental cause and consequence of environmental issues.

\section{Nature, work and gender}

Thus, I suggest that work on gender and environment needs to move away from an explicit focus on how gender structures development and environmental outcomes, to a focus on how gender and environment are mutually constituted. This requires an engagement with the relationships between development projects, subjectivities and re/productive activities, as well as material transformations of ecosystems.

As argued above, gender in this context refers to the processes by which subjectivities are produced. Unlike 'gender roles' (see also Connell 1987), subjectivities are performed and contested through social interactions that are always imbued with power (Butler 1997, Mahoney and Yngvesson 1992). Gender thus does not refer to women or to differences between men and women. Rather gender is the process through which differences based on presumed biological sex are defined, imagined and become significant in specific contexts (Butler 1992, 1997, Mahoney and Yngvesson 1992, Mehta and Bondi 1999, Scott 1991). As Butler (1990, 1997) has argued, gender is performed by subjects and it is only through this performance that gender takes on any meaning at all. Yet these performances are imbued with power and attempts to resist culturally proscribed performances are somewhat contradictory. As Mahoney and Yngvesson (1992) have argued, in order to resist gender domination, subjects must first accept and internalise aspects of this 
domination. For example, as I elaborate below, it is only by accepting a notion of 'women's work' that women can call on aspects of their work to resist new work expectations placed upon them. Central to this understanding, is the notion that the contradictory performance of gender leads to its (re)inscription (Butler 1990) and in combination with the performance other subjectivities including class, race, caste, and ethnicity, is embedded within the (re)production of material and symbolic social inequalities (Kobayashi and Peake 1994).

Butler's work has been crucial in conceptualising how gender is not static but rather is constantly (re)defined and contested in the contexts within which it is invoked (Bondi 1993, Butler 1992, Scott 1991). Yet, most of Butler's work remains highly abstract and how gender plays out in particular contexts and intersects with other aspects of subjectivities is not explored with the same depth as some work in geography has done (Bondi 1993, Bondi and Davidson 2004, Kobayashi and Peake 1994, Massey 1994, McDowell 1999). For example, Pratt and Hanson (1994) argue that place is one context within which gender is constructed. Their research on working class women showed that the material and symbolic meanings of places were significant in shaping women's employment and mobility which in turn shaped ‘women's work' (Hanson and Pratt 1995, Pratt and Hanson 1994).

Butler also fails to take account of how space is not a static background for social relations, but rather space is constructed by social relations and as such is constantly changing (Massey 1994). Doreen Massey (1994) demonstrated how notions of difference produce the form, function and meanings of particular spaces at the same time that social relations are enacted and contested in space. This work in urban geography has shown that conceptualizing space as 'stretched out social relations' (Massey 1994) allows for an examination of how and why 'global' 
processes, such as capitalism, occur differently in different places, with variable and changing consequences for both space and gender relations. More recently, Bondi and Davidson (2004) have argued for a post-structural understanding of the genderspace nexus that demonstrates how subjectivity cannot pre-exist its environment. Drawing from studies on agoraphobia, they demonstrate how the boundaries between subjects and space are not definitive but rather emerge through interaction. Here, I am interested in exploring how place (and environment) are important in defining what it means to be a 'woman' or a 'man', definitions that in Nepal are also embedded within other aspects of subjectivity such as age and caste.

It is thus critical to explore the contexts within which gender and other social relations are performed, contested and (re)produced. The gender-environment nexus is one such context and an important one within development (see also Harris, this volume). Many development projects in agrarian societies are targeted at various aspects of the environment, whether to improve agricultural yields, or to protect soils, forests and wildlife, most of which neglect gender (Adams 1990, Batterbury, et al. 1997, Blaikie and Brookfield 1987, Escobar 1995, West and Brechin 1991). Yet, as political ecologists have shown, all environmental actions are embedded within social fields of power and political economies that shape both the social and ecological outcomes of such interventions (Bebbington and Batterbury 2001, Bryant 1998, Escobar 1995, Peet and Watts 1996a, Swyngedouw 1999). I suggest that by understanding how gender and subjectivity cannot pre-exist the environments in which they emerge, attention to the performance of gender and other aspects of social difference is crucial for understanding how environmental issues come to be 'environmental' in the first place, and why they take the social and ecological shape that they do. Taking this argument into an explicit examination of ecological issues 
means that it is possible to explore how and why similar processes, such as rainforest logging or conservation projects, produce radically different ecological and social consequences in different places.

To explore this nexus, I apply the insights offered by feminist theorizing on gender and space to ecological environments in an explicit way. I want to emphasize that subjectivities are defined and contested in relation to particular ecological conditions and that such specificity has consequences for both gender and environment. Subjectivities are developed relationally and always in the context of power (Mahoney and Yngvesson 1992), but they are also developed in the context of environments (see also Bondi and Davidson 2004, Nelson 1999 for an argument about the need to situate performativity). What this might mean in terms of understanding ecological contexts has not yet been given sufficient attention.

In the next section I focus on the ways in which subjectivities are performed and (re)produced in the context of community forestry in western Nepal in order to tease out the emergence of both gender and ecology. Working the land is a key way in which people shape ecosystems, and also in Nepal, one of the very significant ways in which men and women and different castes are constructed as being different. Thus, one arena for the resistance of gender and caste in Nepal is land use, and specifically work activities. By examining how gender and caste are invoked, contested and complied with in the context of natural resource management, the ways in which these social relations become salient in environmental issues is illuminated.

To make this abstract discussion more concrete, I explore ethnographic events from my fieldwork on community forestry in Nepal. ${ }^{2}$ They illustrate the simultaneous

\footnotetext{
${ }^{2}$ The information for the case study was collected using interviews and participant observation during November, 1993-July, 1994; December, 1997; and December, 1998-August, 1999.
} 
destabilization and reproduction of social relations of power in relation to, and with material consequences for natural resources.

\section{Gender and work in Nepal}

Forests in Nepal are well integrated into agricultural systems and provide leaf litter, timber, firewood, fodder and grazing resources. Given that fuel and chemical agricultural inputs are inconsistently available in most parts of the middle hills, resources from forests are central to many people's livelihoods. They have been the subject of much national and international concern since the early 1970s when Nepal was declared in a state of ecological crisis (Blaikie, et al. 1980, Eckholm 1975, Messerschmidt 1987, Pitt 1986). International experts perceived that Nepal's hillsides were deforesting at dangerous rates, causing massive landslides and soil erosion. In response, development efforts related to forests began in the late 1970s with the advent of pilot community forestry projects (Gilmour and Fisher 1991). Donor agencies such as the World Bank, USAID, and bilateral aid programs quickly sponsored the formation of user-groups throughout the middle hills of Nepal, particularly those districts relatively accessible from the main hill cities of Kathmandu or Pokara (Graner 1997). Community forestry has become a government and foreign donor sponsored project that turns the management of forests over to village usergroups.

Forest management in Nepal has taken a variety of forms historically and some of these regimes persist or continue to influence present management (Bhattarai, et al. 2002, Nightingale 2003). Under the Rana government that ruled Nepal from 1846-1951 forests were granted as payment to military and other government officials, while in other parts, forests were considered property of the state but given to villagers to manage (Regmi 1988). In Mugu district, the user-group I worked with 
had been given the right to manage their forest in 1919 controlled by rules that are surprisingly similar to current community forestry rules (Nightingale 2003, 2004). The village headman was responsible for over-seeing the harvesting of resources and villagers gave him gifts of food in exchange for necessities such as timber and large amounts of leaf litter for insulating houses. According to oral histories, this system worked well and protected the forest from over-use.

In 1957 Nepal's forests were nationalised, giving control over them exclusively to the state. This move was done in part to protect Nepal's forests from what was seen as inappropriate use by villagers. In practice, forest management continued to be done at the village level until much later (Messerschmidt 1987). The headman system persisted in Mugu until approximately the mid-1970s when control and ownership over forests was taken over by the District Forest Office (DFO). At that time, the DFO was located in Jumla, a gruelling two day walk to the south, thus in practice there was virtually no oversight. The villagers lost control of the forest and it was rapidly depleted as people from all over the valley began using it. The establishment of Rara Lake National Park in 1978 at the top of the valley contributed to pressure on resources. People from villages who historically had not used this particular forest now depended on it for most of their resources until community forestry was established in 1992, effectively limiting the number of users.

Community forestry replaced state management-in practice a situation of open access ${ }^{3}$ - by giving village user-groups control over their forests again. Under community forestry, the DFO rangers assist villagers in setting up user-groups and oversee their management activities, but groups have autonomy over daily

\footnotetext{
${ }^{3}$ Open access refers to common pool resources that are not managed by a group of users. By definition, common property refers to common pool resources that are managed by a clear user-group. Community forestry is thus a form of common property and while state management could be as well, the lack of effective oversight led to a situation of open access (Arnold 1998, McKean 1992, Ostrom 1992).
} 
management (Gilmour and Fisher 1991). The programme has become a global model of 'best practices' development because it gives villagers access to necessary resources and has led to clear improvements in forest conditions. It is based in development models that focus on villagers' basic needs, but fundamentally are concerned with protecting 'fragile' forest ecosystems. In the beginning, the projects exclusively grew tree plantations on denuded slopes and prevented villagers from poaching resources (Graner 1997). Overtime, the program changed focus, however, and it is now oriented around 4 main goals: (1) providing for villagers' basic needs, especially for the poorest of the poor; (2) promoting economic development through the sale of forest products; (3) instilling democratic institutions into communities in the hills; and (4) conserving forests (Gilmour and Fisher 1991, Graner 1997). These goals are in many ways embedded within the idea that villagers do not already possess appropriate skills and knowledge to manage their forests and thus community forestry programmes are oriented around such knowledge transfer.

There has been a clear recognition that 'gender' is relevant in community forestry given women's role in collecting forest resources, leading to a focus on women's participation and even the development of some women-only controlled user-groups (Kharel 1993, Nightingale 2002, Springate-Baginski 2000). Here, gender is synonymous with 'women' and is considered primarily an issue of equity and women's empowerment rather than gender relations being a potential cause of forest decline, although to some extent women are also considered to be better custodians of the forest.

The composition of community forestry user-groups is based on either historical claims to forest land, or to current local politics that allow groups to claim exclusive rights to tracts of forest. Once formed, a user-group develops a 
management plan with assistance from the District Forest Office rangers and is required to hold regular meetings, keep accounting records and punish violators of the management plan. The plan is a legally binding document that gives use-rights to the group and also holds the group as a whole accountable to some over-riding national forest rules (such as not building houses within the community forest, or setting forest fires) (Shrestha, et al. 1995). The programme has given user-groups a remarkable amount of autonomy and importantly, allows them to control revenue generated from the sale of some forest products. It is expected that the user-group committee will represent the interests of all users and towards that end the District Forest Office encourages the committee to include women and members of different castes.

These changes in institutional practice have been very significant for forest management in many places (Kanel and Varughese 2000, Springate-Baginski 2000) and particularly in Mugu. The historical systems excluded women and lower-castes from any claim to control over forest resources and certainly must have privileged those with connections to the headman. The status of the headman was thus closely linked to control over forests. This linkage meant that the ecological state of the forest was shaped by the degree to which the headman was respected and had de facto control over it as well as his judgement in granting access. In Mugu, people emphasised that the headman had been 'strong' and universally respected, thus people 'minded', meaning they conformed to his rules. The system also served to constitute hierarchies around caste and gender. The headman was without exception, highest caste and male, and given the importance of forest resources, served to symbolically and materially (re)inscribe high-caste men as those with the most economic and social power. 
State management, however, proved to be worse, and at least in Mugu, people speak bitterly of the situation of open access and rapid depletion of resources that ensued. The power of the village headman was undermined by the loss of control over forests and in many ways, the old respect and power given to him was transferred to the District Forest Officer rangers when an office was established in Mugu. These transformations in gender and caste had tangible ramifications for forest ecosystems as more of the mature timber trees were cut and more animals grazed the understory leading to a thinning forest canopy and low recruitment of seedlings (Nightingale 2001).

These institutional arrangements intersect with locally-based systems of labour allocation and politics around gender, caste and age (Nightingale 2003). Work in the agro-forestry systems of Nepal is highly segregated based on social difference, particularly caste and gender, although class and age intersect with these other relations in interesting ways (Nightingale 2001). Married women notoriously do most of the heavy work related to agricultural production, and while this is empirically substantiated (Agarwal 1994, Gururani 2002, Hobley 1996, Shiva 1988), the focus on women has somewhat obscured the role of the lowest-castes in providing agricultural labour under feudal-type relationships in many places. This is particularly true in the Karnali zone of north-western Nepal where caste and gender relations are complexly intertwined and are based on sharp distinctions concerning who will do particular kinds of work ('conservative' or 'old fashioned' in the words of my Nepalese research assistants).

The community I worked with consists of four castes in three villages who manage a 124 hectare forest: the two highest castes, Brahmins, and Thakuris, live in one village, middle caste Chhetris live in the second village and lowest caste Kamis in 
the third. Caste hierarchies are conceived of and maintained through a system of dietary and spatial practices related to ritual pollution. The Brahmins and Thakuris are considered pure castes that can be polluted through 'unclean' work, food, or spaces occupied by lowest castes. The Chhetris occupy an intermediate position but for most food sharing purposes are considered 'clean' castes. Another very important way in which caste distinctions are defined is in relation to specific work activities and there are many tasks the higher-castes refuse to do. Similarly, gender distinctions are also in part defined and maintained through work and many routine agricultural and household tasks are considered 'women's work' regardless of caste.

Gender and caste then, in this context are constituted in relation to space in a very direct way. The lower castes are not allowed inside the houses of higher (more 'pure') castes. Similarly, menstruating women and those who have recently given birth are considered polluted and restricted from specific work activities and spaces. Women who are ritually polluted are not allowed to leave the animal stables or touch household implements for seven days, longer after giving birth (Bennett 1983). They are thus excluded from doing much of their usual work. While a break from many of their regular tasks, many women complain bitterly about the requirement that they spend their time outside regardless of the weather and are required to cook their own food over an open fire. ${ }^{4}$ Gender is therefore in part defined in relation to particular spaces. A good friend in the village actively contested these spatial restrictions and spent only three days instead of seven in the animal stables when menstruating. Yet, she often justified her behaviour based on her emaciated body, still sick after a bad bout with tuberculosis, such that she hardly resembled a woman's body anymore. This kind of contestation of what it means to be a woman-needing to stay outside

\footnotetext{
${ }^{4}$ The requirement that women sleep outside while menstruating is changing in this area due to Maoist violence in north-western Nepal.
} 
during menstruation - is predicated upon accepting that definition first. She did not claim that menstruation is not polluting, rather that because she was no longer having the physical symptoms of menstruation, she is in some sense only partially a woman and therefore needs to only partially obey the restrictions.

Similarly, lowest caste men and women who 'clean' themselves by avoiding polluting foods and washing with soap (an expensive luxury that most higher-caste families could not afford) are allowed into the outer recesses of people's homes (see also Nightingale 2001) whereas others were restricted to the open roof tops. The coproduction of caste, gender and space in western Nepal therefore is a good example of what Butler calls 'ambivalence' or the process by which the subject is both a product of and a resistance to subordination (Butler 1997 page 11-13). Just as in the above example, it is only by accepting the notion of ritual pollution that opportunities to contest it such as occupying 'pure' spaces arise (see also Mahoney and Yngvesson 1992). This kind of ambivalence is also evident in the two examples below that illustrate the mutual constitution of gender, environment and ecological change.

The community forestry user-group is embedded within these processes of caste and gender subjectivity formation. The group is controlled by high-caste men who are direct descendents of the village headman, and wealthy, educated Chhetri men. They have claimed control over the committee based on their lineage and their literacy skills. Most of the highest-caste men and some Chhetri men are literate whereas very few women and lowest-caste men are, making literacy a marker of high status. Regular meetings are held which are attended by a cross-section of the usergroup but generally Brahmin and Thakuri men from Chaina are in the majority. The committee has a representative from Sangkhola—the wealthiest man from that village — and between two and four women from Chaina and Hernikanth, generally 
wives or in one case, the mother, of prominent men. Within the group, gender, caste and political party membership are key relations that fragment the group. Indeed, in many cases, the issues debated appeared to be only superficially about the forest and were instead conflicts arising from these social relations (Nightingale 2001, 2002, 2003).

The two ethnographic incidents I want to relay both revolved around the harvesting of leaf litter. Leaf litter is mixed with animal manure as the primary source of agricultural fertilizer and the collection of it is done exclusively by women. Most other work, such as planting, gathering firewood for household use and carrying water is done the vast majority of the time by women, but men do participate in these activities depending on their caste, class and the number of women in their household. Collecting leaf litter, however, is virtually never done by men although people said there were not particular cultural or religious reasons why they could not, it is simply considered women's work.

When I was in the field in 1994 the community forest user-group had only been in operation for a year and a half and was still in the process of defining the harvesting restrictions for forest products. At one meeting, a group of Thakuri and Brahmin men proposed limiting the harvesting of leaf litter to two five-day periods a year. The idea was to protect the soil of the forest by leaving leaf litter on the ground for most of the year. From an ecological perspective, this would help reduce erosion and increase the soil fertility of the forest.

The high-caste women at the meeting were very concerned that restricting the harvesting of leaf litter would add substantially to the hours and intensity of their work during those periods and they loudly protested the measure. One Thakuri woman said, "How can we gather enough pine needles for six months in such a short 
period of time? And what will we do if a woman is sick or the daughter-in-law is having a baby during that time?" (community forestry meeting 17 March, 1994). Their concerns were based on both an increase in work and local understandings of gender which include restricting women from doing their regular work after they have given birth.

The issue buzzed through the village and one afternoon a week later a group of Brahmin and Thakuri women speculated about how much they could really gather in that amount of time. Their village is located down in the valley and the forest is a full forty-five minute walk away, further to get to the good places. One woman said that at her natal home they had limited harvesting to just two days. She got up and acted out for us the frantic movements of the women in that village when gathering leaf litter compared to the slow way in which they themselves adjusted their shawls and hoisted their loads. Everyone erupted with peels of laughter, but the point was made; the measure would add to the intensity of their work during those periods of time. I asked if the Chhetri and Kami women were also concerned. A Thakuri woman replied that no, they were not as concerned; the lower-castes lived on the forest boundary and already kept large stockpiles of leaf litter at their houses.

This example illustrates two aspects of the ways in which gender is inscribed in relationship to work and environment and the consequences of this for community forestry. First, leaf litter collection is understood as women's work and thus the new restriction serves to identify women's work with ecological decline. Because the high-caste women preferred to collect small amounts of leaf litter on a continual basis, their work was seen as disrupting the ecological health of the forest. While limiting of leaf litter collection was done based ostensibly on ecological principles it was deeply embedded in women's work. Certainly there was an ecological motivation for 
the new restriction, but it is also not an accident that it was women's work that was seen as expendable by the high-caste men. Their own work was not affected by the new rules.

The high-caste men who control the committee proposed the rule with encouragement from the District Forest Office rangers. The rangers were interested in retaining leaf litter on the forest floor to improve the absorption capacity of the soil and to allow more nutrients from the leaf litter to be integrated into the forest soils. The men believed at some level in these ecological principles, but they also were interested in establishing good relations with the DFO. The DFO staff are a potential source of jobs and favours as well as allies in their local struggles to retain de facto control over their forest. A key way in which they build this alliance is by demonstrating their knowledge of 'scientific forestry' and following the suggestions given by the DFO (Nightingale 2004, Pigg 1996).

The leaf litter restrictions were thus produced out of these overlapping interests, relations and ecologies and enforcing the restriction serves to stabilise them over time and space. This incident then served to bring gender into the forefront of environmental conservation and in the process to re-establish labour relations based on gender. The restriction did not lead to any re-negotiation over men's refusal to participate in leaf litter collection or the value of scientific forestry in building the ecological health of the forest. Thus the issue re-inscribed particular aspects of what it means to be a 'man' and a 'woman' in Mugu and also what it means to conserve the forest.

Second, the Thakuri and Brahmin women's responses themselves could not fundamentally lead to a redefinition or renegotiation of 'women's work'. Rather, as their comical portrayal of the consequences revealed, the women were well aware that 
their own work intensity had increased. In their protests of the measure, they highlighted that gender determines who collects leaf litter, and they drew on discourses of ritual pollution to explain why some women would not be available during the established collection time. In this incident, then 'women's work' as a social category and material practice was (re)produced in relation to the new harvesting restrictions. The importance of ritual pollution in defining which women could do work and which spaces they could occupy was critical to the potency of their protests. Without accepting their ritual pollution and leaf litter collection as their work, the women could not have used this kind of protest. Their protests unsettle somewhat the gender hierarchies, yet by invoking 'women's work' and the castebased distinctions that bound it, they simultaneously (re)inscribed those social inequalities.

The fact that the women were willing to protest at all is very significant. According to local cultural ideas, this is not a usual or necessarily acceptable behaviour for women. Women are expected to obey their husbands, fathers-in-law and other village elders. In most public contexts, women would not defy their husbands and while some women have significant input within more private spaces, nevertheless, women in Mugu spoke of feeling dominated by men especially in relation to controlling key household assets. Yet the women did not hesitate to loudly protest the measure in direct opposition to the husbands of the original two women. I believe this was in part due to the burdensome nature of gathering leaf litter, and also due to the importance of leaf litter to their livelihoods. Without it they cannot expect to get decent crop yields, a point that was emphasised to me many times. Their fear of not having enough and of the work required to obtain it, caused a slight shift in their performances of gender. 
This incident illustrates well the ambivalence of subjectivity performance and how individuals both internalise and resist gender (cf. Butler 1997, Mahoney and Yngvesson 1992) and also how gender is inextricably bound up with caste. The married Brahmin and Thakuri women were on the one hand asserting their authority within the user-group by protesting the measure and speaking out against their husbands, and on the other hand invoking the gender division of labour to do so. They accept that they are expected to do work that men are not, yet they are willing to resist other aspects of power relations between men and women as a result of accepting ‘women's work' (see also Mahoney and Yngvesson 1992). This kind of protest simultaneously destabilises and reproduces gender in the context of community forestry. Gender becomes salient because of both labour relations and rules that target women's work without also targeting men's work, and at the same time, gender subjectivities are contested as the women (re)define in what spaces and contexts they can speak against men considered their superiors. These actions thus make community forestry an important context within which gender is (re)inscribed.

In this example, it is not adequate to imply that gender was the only significant social relation, however. The Chhetri and Kami women had very little to say about the harvesting restriction, largely because they already tended to collect leaf litter at key times of the year rather than small amounts continuously. At the time, they felt it did not affect them much, yet it is also significant that their concerns were not solicited by the user-group before passing the measure. The high-caste women and lower-caste women had different perspectives and they had different motivations to either accept or contest 'women's work' in community forestry, yet the men made decisions about leaf litter that assumed all households would be equally affected. It is important to note that all women's perspectives about the new rules were either not 
solicited or disregarded when passing the measure, (re)enforcing the authority of (some) men to make resource management decisions. In these ways, the performance of gender, as it is intertwined with the performance of caste and labour relations simultaneously divides women of different castes as their work is not identical and serves to lump their concerns together as largely irrelevant.

The other ethnographic incident happened five years later in the spring of 1999 in the same place. That year, due to other internal conflicts, the user-group had been slow to announce the harvest of leaf litter. The Kami women became impatient and decided to harvest what they needed without consulting the user-group. The other women, both from the high-caste village and the Chhetri village, heard about this and decided to confront the Kami women in their village and demand that they pay a fine or turn over their cooking pots as collateral. It is important to note that the highercaste women did not want to bring the Kami women before the user-group to levy a fine, the way rules are normally enforced. Rather, they wanted the women to pay them a fine and therefore keep the conflict outside the boundaries of the formal group. When we arrived in the village, ${ }^{5}$ all the women gathered on a rooftop and started shouting at each other. The higher-caste women loudly asked why the Kami women had harvested out of turn, and demanded that they pay a fine. The Kami women were also talking loudly, but they focused their efforts on eliciting pity. The higher-caste women then insisted on taking the cooking pots. The Kami women, most of whom are very poor, tried to reason with the high-caste women, one said, "oh sahib, don't take our pots, what could you do with them? They are [ritually] polluted, you can't bring them into your house, you will pollute yourself, what do you want with

\footnotetext{
${ }^{5}$ I was with the women at the time which I do think was significant. A large group of women had arranged to go to the forest together with me and I believe it was both the unusually large group and my presence that gave them the authority to go to the Kami village. They did want to settle the issue themselves, the particular context gave them the opportunity.
} 
them?" (participant observation 22 February 1999). The higher-caste women were eventually convinced by this argument and left without the pots, intending to collect the money later.

As in the first example, this incident illustrates the complex and contradictory ways in which both gender and caste are destabilized and reproduced. The low-caste women utilized the discourse of caste-ritual pollution upon which caste divisions are based-to convince the Brahmin and Thakuri women to leave the pots behind. By doing so they did not contest the fundamental logic of caste, rather they reinforced it, indicating that at some level they have internalised the power relations inherent in caste. Yet, they also used caste ideals, which are oppressive to the lower castes, to contest the domination of the higher-caste women. Again, it is by accepting (at some level) the subjectivity of caste that they were able to have an effective weapon to resist the high-caste women's demands (see also Butler 1997, Mahoney and Yngvesson 1992). Thus here when caste and gender are viewed together, different kinds of contestations of oppression and conflicts over resources emerge. Through their acceptance and resistance of caste, the women question and re-establish the boundaries between castes in the same moment. They do this through the physical act of collecting leaf litter from the forest and through their use of caste discourses to resist punishment by the higher-caste women.

The ways in which gender matters to authority within the community forestry user-group was also contested in this incident because the high-caste women were subverting the normal process through which user-group fines are levied by doing it directly themselves. Under community forestry rules, the low-caste women should have been brought before the user-group where they would have paid a fine to the men who control the committee. The Brahmin and Thakuri women were thus 
claiming authority in relation to the lower-caste women that they did not command within the user-group as a whole (Nightingale 2002). Yet, by claiming authority over the regulation of leaf litter collection and over the low-caste women, the high-caste women were simultaneously taking power and reinforcing the idea that harvesting of it is the responsibility of women only.

As in the first example, gender and caste are both significant for who became involved in this particular conflict and the terms under which it was played out. The difficulties of separating gender and caste relations become readily apparent as the performance of gender is inextricably bound up with the performance of caste, marriage and age. It is only married high-caste women who collect leaf litter, whereas both married and unmarried, low-caste women collect it. The harvesting restrictions are burdensome to most women in the user-group (despite the lower-caste women's initial ambivalence about it), a form of oppression imposed by the men who control the committee. The lower-caste women also feel oppressed by the wealthier high-caste women who claim the right to punish their deviant actions, yet they clearly do not accept this domination passively but rather resist it through their actions and words. Such an analysis reveals the unstable ways in which social power is performed and reproduced. It is crucial to explore these contradictions as they provide the potential to contest subjectivities, and also they demonstrate how the act of invoking social difference materially and symbolically simultaneously reproduces them (see also Butler 1997, Gibson-Graham 1996, Kobayashi 1994, McDowell 1999).

Finally, both of these incidents were embedded within particular ecological conditions. The perception of ecological decline catalyzed the formation of the usergroup and is one of the main reasons they are motivated to limit harvesting of key resources. Leaf litter was one of the first resources to become a material and 
symbolic icon for forest conservation. While I am not going to dispute the ecological benefits of leaf litter, I think it is important to recognize that this conservation icon is intimately connected to gender and work. Other harvesting restrictions, such as permits for timber cutting, did not have the same kind of temporal implications for men's work as limiting leaf litter harvesting had on women's work. Timber permits serve to reduce the overall cutting and to provide an income to the group (especially the men who control the group and the low-caste men who do the harvesting) but they do not require that a fixed amount of timber is harvested in a limited time period. The restrictions on leaf litter harvesting, in contrast, were not designed to limit the total amount collected, but rather to retain the litter on the forest floor for more months per year. This necessitated adding a time pressure to women's harvesting activities. It is not men who suffer directly the consequences of limiting harvesting. Yet, since men decided to make the rules, it is clear that women do not always feel compelled to uphold them.

Contestations over social relations can have concrete ecological effects; the Kami women harvesting leaf litter before the prescribed time undermined the ecological benefits of limiting harvesting. In my fieldwork I observed other acts of resistance (cf. Scott 1985) that involved the breaking of user-group rules such as cutting green wood, poaching of timber and grazing animals during restricted times all of which have demonstrable ecological consequences, albeit of varying degrees of importance. Most often these acts were a response by marginalized members (women and lowest-castes, occasionally poor higher-caste men) who felt their needs were not addressed by the user-group rules, or they had not been sufficiently consulted in the formation of the rules. These acts of resistance are significant sources of power for marginalized group members as in the cooking pots example, even if they were not 
necessarily done consciously. Yet, by using these acts of resistance, people have to accept that such tasks are the domain of women and lowest-castes, thus reproducing gender and caste hierarchies and the symbolic meanings of both social difference and natural resources that are associated with women and lowest-castes.

Environmental change is thus in part constituted by material practices and the production of symbolic meanings of resources. In the examples given here, leaf litter harvesting restrictions are as much (if not more) symbolic of environmental conservation as they are of actual environmental change. This insight points to the need for attention to both material practices and symbols across multiple scales. Topdown development programs construct symbolic practices through a focus on particular kinds of resources ${ }^{6}$ (for example firewood or leaf litter rather than multi-use forests) and through assumptions of gender roles within communities. These assumptions (re)enforce particular axes difference making it difficult for marginalized people to effectively contest those subjectivities with variable but significant ecological implications.

These examples also point to the difficulties of separating ecological change from social relations. The kinds of harvesting practices that occur, the extent to which various group members are motivated to uphold harvesting rules and the overall ability of group members to abide by restrictions are all embedded within the social relations-environment nexus. In other words, ecological conditions in part produce the material and symbolic work practices that constitute gender and other subjectivities, at the same time that the contestation and performance of subjectivities shape ecological change. Labour relations thus are constitutive of ecological conditions, a fact that is often neglected by development planners who seek either

\footnotetext{
${ }^{6}$ Indeed, while it is outside the scope of this paper, I would argue that development programs produce resources (Braun and Castree 1998a, Demeritt 1998, 2001).
} 
specific labour outcomes (providing income for marginalised groups) or environmental outcomes (the protection of specific resources), leading to unexpected and often disastrous consequences.

Gender as it intersects with the performance of other subjectivities shapes not only who is involved in what kinds of work and therefore what kinds of issues pertain to community forestry, it also is constituted through the process of community forestry. As a result, evaluations of ecological change and development cannot be isolated from a consideration of the construction of subjectivities within place-based projects.

\section{Conclusion}

In this paper I have outlined the importance of gender and the production of other subjectivities as a central analytical tool for analyzing human-environment interactions. The political ecology literature has emphasized that access to, control over and the distribution of resources are at the core of most environmental issues, both in terms of social inequities and in terms of ecological decline. Who is responsible for creating harvesting rules, who actually does the work and what contestations result, are key aspects of environmental issues. Uncovering the processes by which these occur is critical if we hope to challenge the overexploitation of both land and people. The feminist literature on gender and the performance of other forms of difference provides an analytical entry point for exploring how subjectivities both constitute and are produced by environmental issues. This reconceptualization of gender within natural resource management reveals the ways that gender and caste become salient within community forestry and the ways in which men and women of different castes have a different experience of it. 
When gender is conceptualized as a linear or structuring relation, a consideration of gender in environmental issues leads primarily to the promotion of strategies to equalize the impact on men and women. While such measures can be important, they do not always produce the anticipated outcomes because of the dynamic relationship between gender, environment and other aspects of social and cultural life. Once gender is re-conceptualized as a process, these relationships can be brought into view and examined within environmental debates. My fieldwork examples detail the way in which material and discursive acts of gender and castebased resistance take place within environments and in relation to particular ecological conditions, and thus cannot be understood divorced from the environment. Analyzing gender in this way demonstrates how ecological conditions are both materially and symbolically transformed and reproduced in contradictory ways through the process of contesting social hierarchies. To take this work further it is necessary to ask, what opportunities for positive ecological and social change are produced by understanding the complexities of these processes?

Recognizing the mutual constitution of social relations and environment requires that planners re-evaluate how they formulate development programs. Rather than gender, basic needs or environmental programs, it is necessary to reconceptualise these not as additive processes, but as embedded within each other. In addition, it is crucial to recognize the contingent relationships that intersect at the social relations-environment nexus. It is not possible to develop one formula for the implementation of community forestry that will be sensitive to gender and caste relations in all contexts. In some contexts, other relations such as political party membership or class may be more salient for defining labour relations and contestations over resources, the critical issue is how subjectivities become significant 
and are played out within development projects and in relation to environmental change. What this analysis points to is the need for more attention to how projects are implemented and to allow for sufficient flexibility and attention to the shifting relationships between environment, development and difference.

\section{Acknowledgements}

The research for in Nepal was provided by a Fulbright-Hays Doctoral Dissertation Award and by the National Science Foundation under Grant No. 9900788; in addition it was supported by the MacArthur Program on Global Change, Sustainability, and Justice, the Graduate School and the Department of Geography at the University of Minnesota. I am grateful to Liz Bondi, Charlotte Chambers, Leila Harris, Deborah Thien, Cindi Katz and three anonymous reviewers for extremely useful comments on earlier drafts.

\section{References}

Adams W M, 1990 Green Development (Routledge, New York, NY)

Agarwal B, 1992, "The Gender and Environment Debate: Lessons from India" Feminist Studies 18 119-158

Agarwal B, 1994 A Field of One's Own: Gender and Land Rights in South Asia (Cambridge University Press, Cambridge)

Agarwal B, 1997, "Environmental Action: Gender Equity and Women's Participation" Development and Change 28 1-43

Arnold J E M, 1998, "Managing Forests as Common Property", (Food and Agriculture Organization of the United Nations, Rome)

Barker D K, 2000, "Dualisms, Discourse, and Development", in Decentering the Center: Philosophy for a Multicultural, Postcolonial, and Feminist World Eds U Narayan and S Harding, (Indiana University Press, Indianapolis) pp 177-188

Batterbury S, Forsyth T and Thomson K, 1997, "Environmental Transformations in Developing Countries: Hybrid Research and Democratic Policy" The Geographical Journal 163 126-132

Bebbington A and Batterbury S, 2001, "Transnational Livelihoods and Landscapes: Political Ecologies of Globlalization" Ecumene: A Journal of Cultural Geographies 8 369-380

Bennett L, 1983 Dangerous Wives and Sacred Sisters: Social and Symbolic Roles of High Caste Women in Nepal (Columbia University Press, New York, NY) 
Bhattarai K, Conway D and Shrestha N, 2002, "The Vacillating Evolution of Forestry Policy in Nepal" International Development Planning Review 24 315-338

Blaikie P and Brookfield H, 1987 Land Degradation and Society (Methuen, London)

Blaikie P, Cameron J and Seddon J D, 1980 Nepal in Crisis: Growth and Stagnation in the Periphery (Oxford University Press, Oxford)

Bondi L, 1993, "Locating Identity Politics", in Place and the Politics of Identity Eds M Keith and S Pile, (Routledge, New York) pp 84-101

Bondi L and Davidson J, 2004, "Troubling the Place of Gender", in Handbook of Cultural Geography Eds K Anderson, M Domosh, S Pile and N Thrift, (Sage, London)

Bourque S C and Warren K B, 1981 Women of the Andes: Patriarchy and Social Change in Two Peruvian Towns (The University of Michigan Press, Ann Arbor)

Braun B and Castree N, 1998a Remaking Reality: Nature at the Millenium (Routledge, London)

Braun B and Castree N, 1998b Remaking Reality: Nature at the Millennium (Routledge, New York)

Bryant R L, 1998, "Power, Knowledge and Political Ecology in the Third World: A Review" Progress in Physical Geography 22 79-94

Butler J, 1990 Gender Play: Feminism and the Subversion of Identity (Routledge, New York)

Butler J, 1992, "Contingent Foundations: Feminism and the Question of "Postmodernism"", in Feminist Theorize the Political Eds J Butler and J Scott, (Routledge, London) pp 3-21

Butler J, 1997 The Psychic Life of Power (Stanford University Press, Stanford)

Carney J, 1994, "Contracting a Food Staple in the Gambia", in Living under Contract: Contract Farming and Agrarian Transformation in Sub-Saharan Africa Eds P Little and M Watts, (The University of Wisconsin Press, Madison) pp 167-187

Carney J, 1996, "Converting the Wetlands, Engendering the Environment", in Liberation Ecologies: Environment, Development, Social Movements Eds R Peet and M Watts, (Routledge, New York) pp 165-186

Chant S and Radcliffe S A, 1992, "Migration and Development: The Importance of Gender", in Gender and Migration in Developing Countries Eds S Chant, (Belhaven, London) pp 1-29

Connell R W, 1987 Gender and Power: Society, the Person and Sexual Politics (Polity Press in association with Blackwell, Oxford) 
Cuomo C J, 1998 Ecological Feminism: An Ethic of Flourishing (Routledge, London)

Deere C D, 1990 Household and Class Relations: Peasants and Landlords in Northern Peru (The University of California Press, Berkeley)

Deere C D and Leal M L d, 1981, "Peasant Production, Proletarianization, and the Sexual Division of Labor in the Andes" Signs 7 338-360

Demeritt D, 1998, "Science, Social Constructivism and Nature", in Remaking Reality: Nature at the Millenium Eds B Braun and N Castree, (Routledge, London)

Demeritt D, 2001, "Scientific Forest Conservation and the Statistical Picturing of Nature's Limits in the Progressive-Era United States" Environment and Planning D: Society and Space 19 431-459

Diamond I and Orenstein G F, 1990 Reweaving the World: The Emergence of Ecofeminism (Sierra Club Books., San Francisco)

Eckholm E P, 1975, "The Deterioration of Mountain Environments" Science 189 764770

Escobar A, 1995 Encountering Development: The Making and Unmaking of the Third World)

Fortmann L, 1996, "Gendered Knowledge: Rights and Space in Two Zimbabwe Villages: Reflections on Methods and Findings", in Feminist Political Ecology: Global Issues and Local Experiences Eds D Rocheleau, B Thomas-Slayter and E Wangari, (Routledge, New York) pp 211-223

Freidberg S, 2001a, "To Garden, to Market: Gendered Meanings of Work on an African Urban Periphery" Gender, Place and Culture 8 5-24

Freidberg S E, 2001b, "Gardening on the Edge: The Social Conditions of Unsustainability on an African Periphery" Annals of the Association of American Geographers 91 349-369

Gibson-Graham J K, 1996 The End of Capitalism (as We Knew It) (Blackwell, Cambridge, MA)

Gilmour D A and Fisher R J, 1991 Villagers, Forests and Foresters: The Philosophy, Processes and Practice of Community Forestry in Nepal (Sahayogi Press, Kathmandu)

Gisbert M E and al. e, 1994, "Gender Issues Associated with Labor Migration and Dependence on Off-Farm Income in Rural Bolivia" Human Organization 53 110-122

Graner E, 1997 The Political Ecology of Community Forestry in Nepal, vol. 14, Edited by H-G Bohle (Verl. für Entwicklungspolitik, Saarbrücken) 
Griffin S, 1978 Woman and Nature: The Roaring Insider Her (Harper and Row, New York)

Gururani S, 2000, "Regimes of Control, Strategies of Access: Politics of Forest Use in the Uttarakhand Himalaya, India", in Agrarian Environments: Resources,

Representation and Rule in India Eds A Agrawal and K Sivaramakrishnan, (Duke University Press, Durham and London) pp 170-190

Gururani S, 2002, "Forests of Pleasure and Pain: Gendered Practices of Labor and Livelihood in the Forests of Kumaon Himalayas, India" Gender, Place and Culture 9 229-243

Hanson S and Pratt G, 1995 Gender, Work and Space (Routledge, London)

Haraway D, 1991 Simians, Cyborgs and Women (Routledge, New York)

Hobley M, 1996, "Participatory Forestry: The Process of Change in India and Nepal", (Overseas Development Institute, London)

hooks b, 1984 Feminist Theory: From Margin to Center (South End Press, Boston)

hooks b, 1990 Yearning: Race, Gender and Cultural Politics (South End Press, Boston)

Kanel K and Varughese G, 2000, "Economic Benefits of Decentralizing Forest Management: A Comparative Study of Four Community Forestry User Groups in Nepal", Constituting the Commons: Crafting Sustainable Commons in the New Millennium: Eighth Conference of the International Association for the Study of Common Property, Bloomington, Indiana, USA;

Kharel S, 1993, "Women's Participation in Community Forestry: The Nepal-Australia Community Forestry Project's Experience" Banko Janakari 4 73-75

Kobayashi A, 1994, "Coloring the Field: Gender, "Race," and the Politics of Fieldwork" Professional Geographer 46 73-80

Kobayashi A and Peake L, 1994, "Unnatural Discourse, 'Race' and Gender in Geography" Gender, Place and Culture $1225-243$

Latour B, 1993 We Have Never Been Modern (Harvard University Press, Cambridge)

Mackenzie F, 1995, "Selective Silence: A Feminist Encounter with Environmental Discourse in Colonial Africa", in Power of Development Eds J Crush, (Routledge, New York) pp 100-112

Mahoney M A and Yngvesson B, 1992, "The Construction of Subjectivity and the Paradox of Resistance: Reintegrating Feminist Anthropology and Psychology" Signs 18 44-73 
Massey D, 1994 Space, Place and Gender (University of Minnesota Press, Minneapolis)

McDowell L, 1999 Gender, Identity and Place: Understanding Feminist Geographies (University of Minnesota Press, Minneapolis)

McKean M A, 1992, "Success on the Commons: A Comparative Examination of Institutions for Common Property Resource Management" Journal of Theoretical Politics 43 247-281

Mehta A and Bondi L, 1999, "Embodied Discourse: On Gender and Fear of Violence" Gender, Place and Culture 6 67-84

Merchant C, 1982 The Death of Nature: Women, Ecology and the Scientific Revolution (Wildwood, London)

Messerschmidt D A, 1987, "Conservation and Society in Nepal: Traditional Forest Management and Innovative Development", in Lands at Risk in the Third World: Local-Level Perspectives Eds PD Little, MM Horowitz and AE Nyerges, Monographs in Development Anthropology, (Westview Press, Boulder) pp 373-397

Mies M and Shiva V, 1993 Ecofeminism (Kali for Women, London)

Moeckli J and Braun B, 2001, "Gendered Natures: Feminism, Politics, and Social Nature", in Social Nature: Theory, Practice and Politics Eds N Castree and B Braun, (Blackwell, Oxford) pp 112-132

Moraga C and Anzaldua G, 1988 This Bridge Called My Back: Writings by Radical Women of Color (Women of Color Press, New York)

Moser C O N, 1993 Gender Planning and Development: Theory, Practice and Training (Routledge, London)

Nathen D, 1995, "A Gender Framework for Resource Management", (Asian Watershed Management Network, Kathmandu)

Nelson L, 1999, "Bodies (and Spaces) Do Matter: The Limits of Performativity" Gender, Place and Culture 6 331-353

Nesmith c and Radcliffe S, 1993, "(Re)Mapping Mother Earth: A Geographical Perspective on Environmental Feminisms" Environment and Planning D: Society and Space 11 379-394

Nightingale A J, 2001 A 'Trialectic' of Community Forestry Management in Mugu District, Western Nepal: Power, Cultural Meanings and Ecology Doctoral Dissertation Thesis, Geography Department, University of Minnesota, Minneapolis

Nightingale A J, 2002, "Participating or Just Sitting In? The Dynamics of Gender and Caste in Community Forestry" Journal of Forestry and Livelihoods 2 
Nightingale A J, 2003, "Nature-Society and Development: Cultural, Social and Ecological Change in Nepal" Geoforum

Nightingale A J, 2004, " 'the Experts Taught Us All We Know': Professionalisation and Knowledge in Nepalese Community Forestry" Antipode manuscript under review

Ortner S, 1974, "Is Female to Male as Nature Is to Culture?" in Women, Culture, and Society Eds Ra Lamphere, (Stanford University Press, Stanford) pp 67-87

Ostrom E, 1992, "The Rudiments of a Theory of the Origins, Survival, and Performance of Common-Property Institutions", in Making the Commons Work: Theory, Practice, and Policy Eds D Bromley, (ICS Press, San Francisco)

Peet R and Watts M, 1996a Liberation Ecologies: Environment, Development, Social Movements (Routledge Press, New York)

Peet R and Watts M, 1996b, "Liberation Ecology: Development, Sustainability, and Environment in an Age of Market Triumphalism", in Liberation Ecologies:

Environment, Development, Social Movements Eds R Peet and M Watts, (Routledge Press, New York)

Pigg S L, 1996, "The Credible and the Credulous: The Question of "Villagers' Beliefs" in Nepal" Cultural Anthropology 11 160-201

Pitt D C, 1986, "Crisis, Pseudocrisis, or Supercrisis. Poverty, Women, and Young People in the Himalaya: A Survey of Recent Developments" Mountain Research and Development 6 119-131

Plumwood V, 1991, "Nature, Self, and Gender: Feminism, Environmental Philosophy, and the Critique of Rationalism" Hypatia 6 3-27

Pratt G and Hanson S, 1994, "Geography and the Construction of Difference" Gender, Place and Culture 1 5-29

Radcliffe S A, 1992, "Mountains, Maidens and Migration: Gender and Mobility in Peru", in Gender and Migration in Developing Countries Eds S Chant, (Belhaven, London) pp 30-48

Reed M G, 2000, "Taking Stands: A Feminist Perspective on 'Other' Women's Activism in Forestry Communities of Northern Vancouver Island" Gender, Place and Culture 7 363-387

Regmi M C, 1988 An Economic History of Nepal 1846-1901 (Nath Printing House, Varanasi)

Rocheleau D and Edmunds D, 1997, "Women, Men and Trees: Gender, Power and Property in Forest and Agrarian Landscapes" World Development 25 1315-1371 
Rocheleau D, Ross L and Morrobel J, 1996a, "From Forest Gardens to Tree Farms: Women, Men and Timber in Zambrana-Chacuey, Dominican Republic", in Feminist Political Ecology: Global Issues and Local Experiences Eds D Rocheleau, B ThomasSlayter and E Wangari, (Routledge, New York)

Rocheleau D, Thomas-Slayter B and Wangari E, 1996b, "Gender and Environment: A Feminist Political Ecology Perspective", in Feminist Political Ecology: Global Issues and Local Experiences Eds D Rocheleau, B Thomas-Slayter and E Wangari, (Routledge, New York) pp 3-26

Schroeder R A, 1997, "'Re-Claiming" Land in the Gambia: Gendered Property Rights and Environmental Intervention" Annals of the Association of American Geographers 87 487-508

Schroeder R A and Neumann R P, 1995, "Manifest Ecological Destinies: Local Rights and Global Environmental Agendas" Antipode 27 321-324

Schroeder R A and Suryanata K, 1996, "Gender, Class Power in Agroforestry Systems: Case Studies from Indonesia and West Africa Peet", in Liberation Ecologies: Environment, Development, Social Movements Eds R Peet and M Watts, (Routledge, New York) pp 188-204

Scott J, 1991, "The Evidence of Experience" Critical Inquiry 17 773-797

Scott J C, 1985 Weapons of the Weak: Everyday Forms of Peasant Resistance (Yale University Press, New Haven)

Seager J, 1993 Earth Follies: Coming to Feminist Terms with the Global Environmental Crisis (Routledge, New York)

Shiva V, 1988 Staying Alive: Women, Ecology, and Development (Zed Books, London)

Shrestha M L, Joshi S P, Bhuju U R, Joshi D B and Gautam M, 1995 Community Forestry Manual (HMG Ministry of Forests and Soils Conservation, Kathmandu)

Sneddon C S, 2000, "'Sustainability' in Ecological Economics, Ecology and Livelihoods: A Review" Progress in Human Geography 24 521-549

Springate-Baginski O, 2000, "Community Forestry Policy in Nepal: Progress and Potentials", 29th Annual Conference on South Asia, University of Wisconsin-Madison, WI;

Sundberg J, 1998, "Ngo Landscapes in the Maya Biosphere Reserve, Guatemala" Geographical Review 88 388-412

Swyngedouw E, 1999, "Modernity and Hybridity: Nature, Regeneracionismo, and the Production of Spanish

Waterscape, 1890-1930" Annals of the Association of American Geographers 89 443-465 
Wangari E, Thomas-Slayter B and Rocheleau D, 1996, "Gendered Visions for Survival: Semi-Arid Regions in Kenya", in Feminist Political Ecology: Global Issues and Local Experiences Eds D Rocheleau, B Thomas-Slayter and E Wangari, (Routledge, New York)

Warren K J, 1987, "Feminism and Ecology: Making Connections" Environmental Ethics 9 3-20

Warren K J and Cheney J, 1991, "Ecological Feminism and Ecosystem Ecology" Hypatia 6 179-197

West P C and Brechin S R, 1991, "Resident Peoples and National Parks: Social Dilemmas and Strategies in International Conservation". Tucson: The University of Arizona Press

Zimmerer K S, 2000, "The Reworking of Conservation Geographies: Nonequilibrium Landscapes and Nature-Society Hybrids" Annals of the Association of American Geographers 90 356-369 